\title{
PELATIHAN PEMBUATAN HAND SANITIZER ALAMI BERBAHAN DAUN SIRIH DAN BATANG SEREH
}

\author{
Asep Suryana Abdurrahmat ${ }^{1}$, Acep Zoni Saeful Mubarok ${ }^{2}$, Ai Nur Sholihat ${ }^{3}$, Ridwan Gumilar ${ }^{4}$ \\ ${ }^{1}$ Jurusan Kesehatan Masyarakat, ${ }^{2}$ Jurusan Ekonomi Syariah, ${ }^{3}$ Jurusan Pendidikan Ekonomi, \\ ${ }^{4}$ Jurusan Pendidikan Jasmani, Universitas Siliwangi \\ Jl. Siliwangi No. 24, Tasikmalaya, Jawa Barat, Indonesia \\ *Korespondensi: ainursolihat@unsil.ac.id
}

\begin{abstract}
Abstrak
Pandemi Covid-19 yang disebabkan oleh viris $n$ Cov-19 berlangsung secara cepat. Hal ini disebabkan kemampuan virus tersebut menyebar melalui kontak langsung antar sesame manuaia. Selain upaya social/physical distancing, upaya lain yang harus dilakukan untuk menekan penyebaran virus ini adalah dengan menjaga kebersihan probadi, diantaranya dengan sering mencuci tangan menggunakan sabun atau membilas tangan dengan menggunakan antiseptik/hand sanitizer. Tingginya permintaan handsanitizer mengakibatkan melambungnya harga dan terjadi kelangkaan di pasar. Oleh karena itu perlu dilakukan inovasi oleh masyarakat dalam pembuatan hand sanitizer yang mudah, murah namun tetap efektif dalam membunuh mokroba. Daun sirih dan batang sereh dipilih menjadi bahan utama dalam pembuatan hand sanitizer alami karena daun sirih dan batang sereh ini memiliki kandungan zat yang dapat dipergunakan untuk antiseptic dan mudah didapatkan. Pembuatan hand sanitizer ini menggunakan metode dan peralatan yang sedehrana. Target peserta dalam pelatihan ini adalah warga Dusun Cikadongdong dan Pesantren Dadali Dinillah Kampung Agra Kecamatan Cikadongdong Kota Tasikmalaya. Monitoring dan evaliasi dilakukan dengan cara memberikan kuesioner yang diberikan kepada 33 orang peserta pelatihan. Sebagian besar peserta pelatihan atau sebesar 75,76\% menyatatakan sangat setuju bahwa materi pelatihan disampaikan dengan jelas dan mudah dipahami, 90,91\% menyatakan sangat setuju bahwa bahan dasar pembuatan hand sanitizer mudah didapatkan, 45,45\% cara pembuatan hand sanitizer alami sangat mudah, 90,91\% pengemasan sangat mudah dan 84,85\% menyatakan bahwa hand sanitizer alami ini sangat bermanfaat dan dapat dijadikan alternatif sebagai antiseptik pencuci tangan.
\end{abstract}

Kata kunci: Covid-19, hand sanitizer

\section{ANALISIS SITUASI}

Corona virus disease atau lebih dikenal dengan Covid-19 merupakan suatu penyakit yang disebabkan oleh terpaparnya individu oleh virus corona strain beta. Berbeda dengan virus corona strain alfa, maka jenis corona strain beta memiliki tingkat 
virulensi yang lebih tinggi sehingga jumlah kasus serta tingkat kematiannya lebih tinggi jika dibandingkan dengan virus corona strain alfa.

Virus corona yang merebak di akhir tahun 2019 merupakan strain baru yang belum pernah ditemukan sebelumnya dan diduga merupakan hasil mutase dari virus corona strain beta sebelumnya. Oleh karena itu jenis virus corona ini disebut Novelcorona virus-19 atau nCov-19 (Wibawa, 2020). Beberapa ahli yang tergabung dalam Coronavirus Study Group (CGS) dalam laporan yang dimuat pada jurnal BIOR edisi XIV menyebut jenis virus ini dengan nama SARS-CoV-2 merujuk pada lokasi penyerangan virus tersebut yang memiliki kemiripan dengan virus penyebab severe acute respiratory syndrom (SARS).

Pada awal mula kasus Covid-19 terjadi diduga diakibatkan oleh penularan dari hewan mamalia (kelelawar) kepada manusia yang terjadi di wilayah Wuhan dataran China. Namun demikian terjadi mutase virus ini sehingga memiliki kemampuan penularan antar manusia. Transmisi yang terjadi selanjutnya adalah melalui percikan droplet saat orang yang terpapar batuk atau bersin yang selanjutnya droplet tersebut terhirup oleh orang sehat. Berdasarkan laporan CGS, hanya dibutuhkan waktu 15 detik untuk melakukan proses penularan virus corona kepada orang lain. Akibatnya jumlah kasus Covid-19 meningkat dengan cepat dan seiring mobilitas manusia maka dengan segera Covid-19 menjadi pandemi.

Melihat model transmisi antar personal dari nCov-19, maka perlu dilakukan pembatasan mobilitas masyarakat secara luas agar terjadi physical distancing yang mampu mereduksi kemungkinan interaksi personal atau social distancing. Upaya tersebut memiliki konsekwensi yang cukup besar sebab dengan adanya pembatasan mobilitas dan aktifitas setiap orang maka akan muncul masalah penurunan tingkat ekonomi yang tajam serta tingkat kejenuhan yang tinggi sehingga pada akhirnya akan memicu berbagai masalah sosial di masyarakat.

Hal yang lebih penting untuk dilakukan agar penyebaran nCov-19 ini bisa dicegah adalah dengan menjaga hygiene personal serta sanitasi lingkungan sekitar dengan baik dan benar. Selain rutin menjaga kebersihan diri dengan cara mandi 2 kali sehari, maka sangat dianjurkan juga untuk sering mencuci tangan dengan menggunakan sabun atau membasuh tangan dengan menggunakan hand sanitizer yang merupakan cairan antiseptik atau zat yang memiliki kemampuan membunuh mikroba, termasuk di dalamnya virus.

Meningkatnya kesadaran masyarakat untuk menjaga kebersihan badan berimplikasi terhadap tingginya minat masyarakat untuk menggunakan hand sanitizer yang dianggap jauh lebih praktis dibandingkan dengan mencuci tangan menggunakan air dan sabun. Hal ini memicu kenaikan harga yang sangat tajam serta sulitnya 
mendapatkan hand sanitizer di pasaran. Untuk mengatasi hal tersebut maka perlu dilakukan upaya untuk pembuatan hand sanitizer secara mandiri dengan menggunakan bahan dasar alami seperti beberapa tanaman obat yang mudah diperoleh di lingkungan sekitar.

Sebagai kearifan lokal, masyarakat Indonesia khususnya di Tasikmalaya yang sudah sejak lama menggunakan berbagai bagian tanaman untuk mencegah terjadinya infeksi oleh mikroba. Diantara tanaman yang memiliki khasiat antiseptik adalah getah batang pisang, umbi kunyit, getah jarak, batang sereh dan daun sirih serta masih banyak lagi tanaman lainnya.

Daun sirih memiliki kandungan berbagai senyawa kimia, diantaranya phenilpropana, minyak atsiri, hidroksikavikol estragol, kavicolkavibetol, allypyrokatekol, caryophilenne, cineole, cadinene, diastase, tanin, dan sekuiterpena. Zat kimia tersebut memiliki kemampuan untuk menghambat pertumbuhan mikroba antara lain dengan cara mencegah pembentukan lemak, protein atau DNA/RNA mikroba serta mengoksidasi dan mendehidrasi mikroba (Suprapto, 2014).

Adapun batang sereh memiliki kandungan mineral (kafaktor) seperti kalium, kalsium, tembaga, selenium, magnesium dan seng. Selain itu batang sereh juga kaya akan vitamin (koenzim) seperti niasin, riboflavin, thiamin dan piridoksin. Kedua jenis senyawa kimia tersebut memiliki peranan penting sebagai katalis dalam berbagai reaksi kimia (Murray, 2012).

Berbagai Teknik pengolahan daun sirih dan batang sereh telah banyak digunakan. Umumnya Teknik yang dipakai adalah ekstraksi dengan mengguanakn pelarut organic seperti alkohol. Teknik tersebut dapat menghasilkan ekstrak dengan kandungan kimia yang tinggi dan murni. Namun demikian untuk pengolahan dengan Teknik ekstraksi diperlukan sejumlah peralatan yang khusus serta sulit diperoleh masyarakat. Oleh karena itu perlu dilakukan pengolahan dengan teknik yang lebih sederhana dengan menggunakan peralatan yang umumnya dimiliki oleh masyarakat. Salah satu teknik yang bisa dikembangkan secara massal adalah metode infusida dengan menggunakan pelarut air yang memiliki suhu di atas $70^{\circ} \mathrm{C}$. Untuk memperoleh hasil yang baik maka infusida kedua tanaman tersebut selanjutnya disaring secara berulang kali dengan menggunakan kain yang bersih. Produk yang dihasilkan dengan metode ini memang memiliki kandungan kimia yang lebih rendah dibandingkan dengan metode ekstraksi tetapi tetap bisa digunakan sebagai antiseptik atau hand sanitizer yang mampu mencegah perkembangan mikroba. Selain murah dan mudah dibuat, hand sanitizer dengan bahan dasar kedua tanaman tersebut memiliki aroma yang tidak menyengat, tidak memiliki efek samping terhadap kesehatan kulit serta memberikan sensasi rasa hangat saat digunakan. 


\section{METODE PELAKSANAAN}

Terjadi peningkatan kasus Covid-19 akibat terpapar SARS-CoV-2/nCov-19 dengan data per 8 Juni 2020 di Kota Tasikmalaya sebanyak 51 kasus dan di Kabupaten Tasikmalaya sebanyak 4 kasus. Kasus pertama covid-19 di wilayah Tasikmalaya terdeteksi pada akhir Maret 2020 dan meningkat tajam saat terjadinya eksodus masyarakat Tasikmalaya yang bekerja di berbagai kota besar seperti Bandung, Jakarta dan sekitarnya Kembali ke kampung halaman akibat sulitnya mendapatkan penghasilan di kota asal.

Mobilitas masyarakat yang tinggi membuat transmisi virus antar wilayah menjadi terbuka lebar dan sulit dikendalikan. Berbagai upaya pembatasan dan penyekatan telah dilakukan oleh pemerintah daerah baik provinsi maupun kabupaten dan kota. Namun demikian, aktifitas masyarakat yang didorong oleh kebutuhan hidup membuat pembatasan dan penyekatan tersebut kurang efektif.

Kecamatan Singaparna yang menjadi ibukota Kabupaten Tasikmalaya merupakan daerah penyangga karena berbatasan langsung dengan Kota Tasikmalaya. Pergerakan masyarakat keluar masuk kedua wilayah tersebut sangat tinggi yang berakibat mudahnya penyebaran Covid-19 diantara kedua wilayah. Pencegahan dengan menggunakan metode pembatasan ruang gerak penduduk Kota dan Kabupaten Tasikmalaya di wilayah Singaparna sulit dilakukan. Oleh karena itu selain upaya pembatasan ruang gerak/social distancing maka perlu dilakukan upaya lain untuk meningkatkan kesadaran masyarakat dalam menjaga diri mereka agar tidak terpapar virus saat beraktifitas. Penggunaan masker dan kesadaran membersihkan tangan menjadi suatu keharusan dan kebutuhan masyarakat.

Sasaran kegiatan ini adalah para tokoh masyarakat yang tinggal di 3 dusun serta pengurus pesantren Dadali Dinillah yang ada di wilayah Desa Cikadongdong Kecamatan Singaparna Kabupaten Tasikmalaya. Dipilihnya kedua kelompok ini mengingat wilayah Kabupaten Tasikmalaya memiliki ikatan yang kuat dengan pesantren sebagai pusat penyebaran dan pengembangan agama Islam yang menjadi nilai utama masyarakat Desa Cikadongdong. 
Alur metode pelaksanaan kegiatan pelatihan pembuatan antiseptik/hand sanitizer alami dengan menggunakan bahan batang sereh dan daun sirih dalam rangka mencegah penyebaran Covid-19 dapat dilihat pada gambar 1.

\begin{tabular}{|l|l|}
\hline \begin{tabular}{l} 
Awal : Group Empowerment $\begin{array}{l}\text { Mengidentifikasi pengetahuan siswa } \\
\text { melalui quiz }\end{array}$ \\
\cline { 2 - 3 }
\end{tabular} & $\begin{array}{l}\text { Pembuatan materi pegangan sasaran yang } \\
\text { meliputi : } \\
\text { 1. Panduan praktis “ Pembuatan antiseptik/hand } \\
\text { sanitizer alami dari daun sirih dan batang } \\
\text { sereh" } \\
\text { 2. Slide dan video }\end{array}$ \\
\hline $\begin{array}{l}\text { Pelatihan Kelompok Masyarakat } \\
\text { Metode Penyampaian materi : } \\
\text { ceramah, tanya jawab, diskusi , } \\
\text { praktek }\end{array}$ & $\begin{array}{l}\text { Pembentukan Kelompok Produsen } \\
\text { Membuat komitmen kesediaan untuk menjadi } \\
\text { produsen dan menjaga suplai }\end{array}$ \\
\hline $\begin{array}{l}\text { Tim akan memantau dan menilai } \\
\text { pengetahuan serta praktek } \\
\text { pembuatan antiseptik/hand sanitizer }\end{array}$ & $\begin{array}{l}\text { Evaluasi program : } \\
\text { Menilai pengetahuan dan kemampuan kelompok } \\
\text { produsen serta menguji penerimaan konsumen } \\
\text { terhadap produk yang dihasilkan }\end{array}$ \\
\hline
\end{tabular}

Gambar 1. Alur metode pelaksanaan kegiatan pengadian kepada masyarakat Sumber: Tim Pengabdian, 2020

Kegiatan pelatihan pembuatan antiseptik alami sebagai hand sanitizer yang murah dan mudah dibuat meliputi langkah-langkah sebagai berikut :

1. Penyusunan materi pelatihan/panduan pembuatan antiseptik alami. Tujuan kegiatan ini adalah menyediakan materi pelatihan/paduan pembuatan antiseptic alami sebagai hand sanitizer agar seluruh masyarakat dan pengurus pesantren mudah membuat hand sanitizer yang murah. Adapun materi pelatihan yang disusun meliputi (a) panduan praktis "Pembuatan Antiseptik/Hand Sanitizer Alami Dari Daun Sirih dan Batang Sereh", (b) salindia dan video proses pembuatan

2. Pembentukan produsen antiseptik/hand sanitizer. Tujuan kegiatan ini adalah membentuk kelompok masyarakat yang mampu membuat antiseptik/hand sanitizer alami dari daun sirih dan batang sereh

3. Pelatihan pembuatan antiseptik/hand sanitizer alami dari daun sirih dan batang sereh. Tujuan kegiatan ini adalah kelompok masyarakat mampu memproduksi antiseptik/hand sanitizer alami dari daun sirih dan batang sereh secara mandiri. Materi yang diberikan berupa (a) pengetahuan praktis kandungan kimia batang 
sereh dan daun sirih, (b) peralatan sederhana yang dapat digunakan untuk produksi, (c) tahapan pembuatan antiseptik/hand sanitizer alami dari daun sirih dan batang sereh, (d) kalkulasi kebutuhan antiseptik untuk seluruh kelompok

4. Evaluasi hasil pelatihan. Tujuan kegiatan ini adalah (a) menilai atau mengevaluasi pengetahuan kelompok masyarakat mengenai pemanfaatan tanaman sereh dan siri dalam pencegahan penyebaran Covid-19, (b) melakukan upaya quality control terhadap produk antiseptik/hand sanitizer alami yang dihasilkan. Evaluasi dilakukan dengan membandingkan produk yang dihasilkan masyarakat dengan produk standar yang telah dibuat dan diuji coba. Selain itu dilakukan juga uji penerimaan konsumen terhadap produk antiseptik/hand sanitizer alami yang dihasilkan.

\section{PELAKSANAAN DAN HASIL}

Kegiatan pelatihan ini diawali dengan pemberian materi pelatihan mengenai pentingnya melaksanakan protocol kesehatan dalam memutus mata rantai penyebaran Cobid-19. Berdasarkan analisis situasi perkembangan Virus Corona (Covid-19) Indonesia yang belum dapat dikendalikan hingga bulan Agustus dan September 2020, muncul kasus baru Covid -19 dengan banyaknya cluster keluarga dan perkantoran. Pemerintah juga sudah memperbolehkan masyarakat untuk melaksanakan aktivitas di luar rumah dengan menerapkan protocol kesehatan yang ketat.

Pada masa transisi menuju adaptasi kebiasaan baru, penerapan protocol kesehatan perlu dilakukan dalam upaya memutus mata rantai penyebaran Covid-19. Pembatasan mobilitas masyarakat secara luas agar terjadi physical distancing yang mampu mereduksi kemungkinan interaksi personal atau social distancing serta upaya lain untuk meningkatkan kesadaran masyarakat dalam menjaga diri mereka agar tidak terpapar virus saat beraktifitas. Penggunaan masker dan kesadaran membersihkan tangan menjadi suatu keharusan dan kebutuhan masyarakat.

Hal yang lebih penting untuk dilakukan untuk memutus rantai penyebaran Covid-19 ini bisa dilakukan dengan menjaga hygiene personal serta sanitasi lingkungan sekitar dengan baik dan benar. Selain rutin menjaga kebersihan diri dengan cara mandi 2 kali sehari, maka sangat dianjurkan juga untuk sering mencuci tangan dengan menggunakan sabun atau membasuh tangan dengan menggunakan hand sanitizer yang merupakan cairan antiseptik atau zat yang memiliki kemampuan membunuh mikroba, termasuk di dalamnya virus.

Dengan melihat fenomena tersebut, kami tim Pengabdian Kepada Masyarakat Skema Kesehatan (PbM-Sk) terpanggil untuk memberikan edukasi dan pelatihan kepada masyarakat dengan memberikan workshop pembuatan handsanitizer alami. Dengan 
pelaksanaan PBM-Sk ini mendorong peningkatan kesadaran masyarakat untuk menerapkan hygiene personal serta sanitasi lingkungan sekitar dengan baik dan benar. Meningkatnya kesadaran masyarakat untuk menjaga kebersihan badan berimplikasi terhadap tingginya minat masyarakat untuk menggunakan hand sanitizer yang dianggap jauh lebih praktis dibandingkan dengan mencuci tangan menggunakan air dan sabun. Hal ini memicu kenaikan harga yang sangat tajam serta sulitnya mendapatkan hand sanitizer di pasaran. Untuk mengatasi hal tersebut maka perlu dilakukan upaya untuk pembuatan hand sanitizer secara mandiri dengan menggunakan bahan dasar alami seperti beberapa tanaman obat yang mudah diperoleh di lingkungan sekitar.

Pengabdian Kepada Masyarakat Skema Kesehatan (PbM-SK) ini telah dilaksanakan pada tanggal 25 September 2020 bertempat di Dusun Desa Cikadongdong dan Pesantren Dadali Dinillah yang berada di Kp. Gunung Agra wilayah Desa Cikadongdong Kecamatan Singaparna Kabupaten Tasikmalaya. Kegiatan yang dilakukan dalam pengabdian ini adalah Pembuatan hand sanitizer dari bahan alami. Pembuatan hand sanitizer diberikan dalam bentuk pelatihan (workshop) yang dihadiri oleh 33 orang peserta dari Dusun Desa Cikadongdong, siswa dan pengurus Pesantren Dadali Dillah. Kegiatan workshop tersebut diliput oleh Harian Radar Tasik dan terbit pada tanggal 26 September 2020. Pelaksanaan PbM-SK ini sudah selesai dilaksanakan dari penyusunan materi pelatihan/panduan pembuatan antiseptik alami sampai dengan tahap pelaksanaan pengabdian.

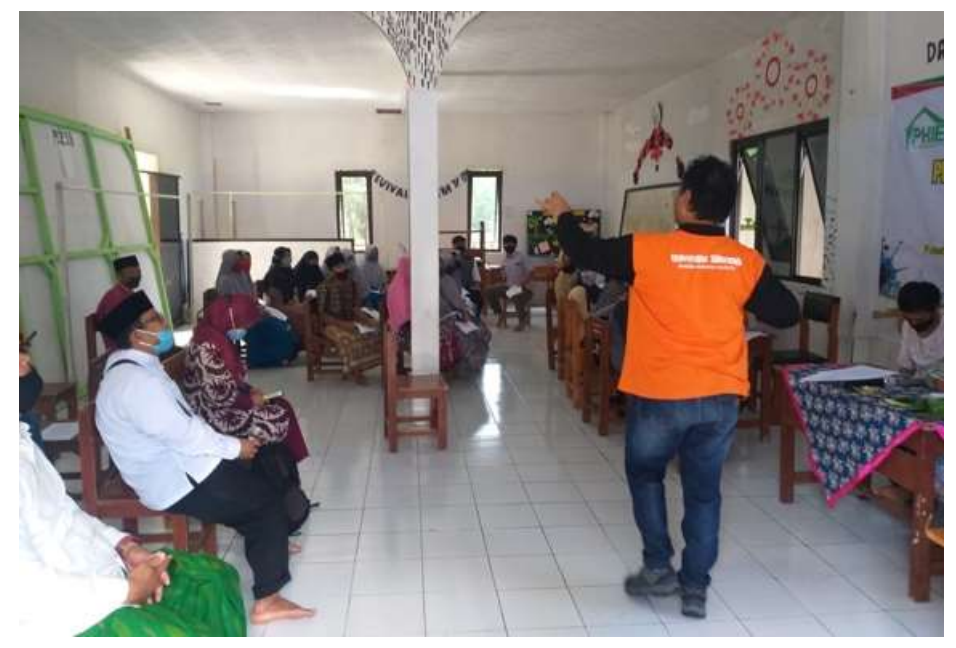

Gambar 2. Pemberian edukasi cara pembuatan hand sanitizer alami Sumber: Dokumentasi tim PbM-SK, 2020

Pada tahap pelaksanaan ini, seluruh peserta diberikan materi mengenai cara membuat hand sanitizer alami dan edukasi mengenai pentingnya kebutuhan pembersih tangan 
untuk menjaga kesehatan masyarakat dan para santri, kemudian dilanjutkan dengan diskusi dan tanya jawab. Setelah pemberian materi dan diskusi dilanjutkan dengan praktik pembuatan hand sanitizer alami berbahan batang sereh, dan daun sirih. Pemberian materi disampaikan oleh Dr. Asep Suryana Abdurrahmat, M.Kes.

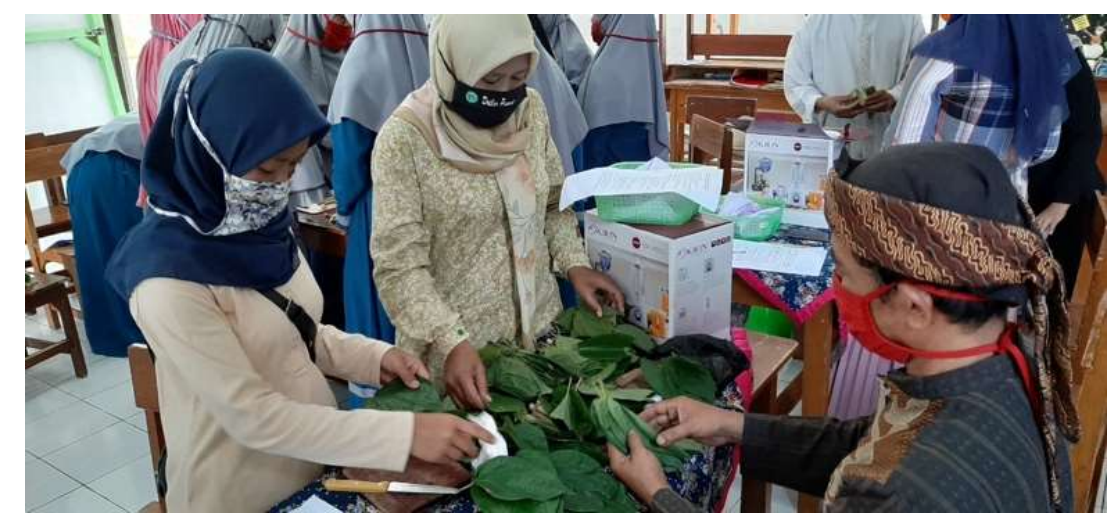

Gambar 3. Praktek pembuatan hand sanitizer di Dusun Desa Cikadongdog Sumber: Dokumentasi tim PbM-SK, 2020

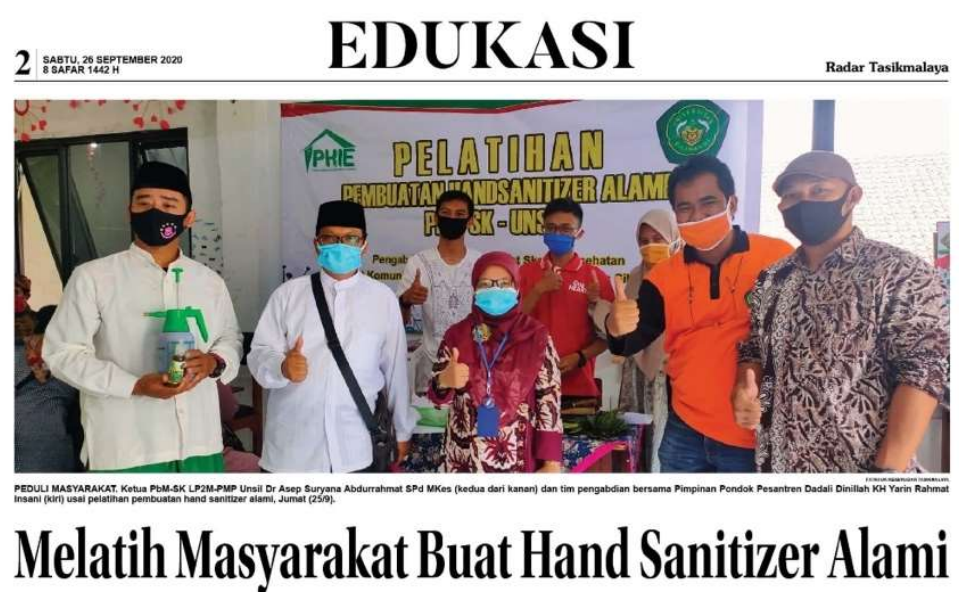

Gambar 4. Cuplikan publikasi di Harian Umum Radar Tasikmalaya Sumber: Dokumentasi tim PbM-SK, 2020

\section{Monitoring dan Evaluasi}

Untuk mengetahui keberhasilan pelatihan dan kebermanfaatan dalam pembuatan hand sanitizer berbahan dasar alami daun sirih dan batang serai, Tim kegiatan PbMSK melakukan monitoring dan evaluasi terhadap hasil pelatihan. Monitoring dan evaluasi dilakikan dengan cara memberikan instrument atau kuesioner kepada peserta pelatihan dengan menggunakan skala likert. Berikut hasil monitoring dan evaluasi. 
Tabel 1. Hasil Evaluasi Pelaksanaan PbM-SK

\begin{tabular}{|c|c|c|c|c|c|c|}
\hline & $\begin{array}{l}\text { Sangat } \\
\text { Setuju }\end{array}$ & Setuju & Ragu & $\begin{array}{l}\text { Tidak } \\
\text { Setuju }\end{array}$ & $\begin{array}{c}\text { Sangat } \\
\text { Tidak } \\
\text { Setuju }\end{array}$ & Total \\
\hline $\begin{array}{l}\text { Materi pelatihan disampaikan } \\
\text { dengan jelas dan mudah dipahami }\end{array}$ & 75,76 & 24,24 & - & - & - & 100 \\
\hline $\begin{array}{l}\text { Bahan dasar pembuatan hand } \\
\text { sanitizer mudah didapatkan }\end{array}$ & 90,91 & 9,09 & - & - & - & 100 \\
\hline $\begin{array}{l}\text { Cara pembuatan hand sanitizer alami } \\
\text { sangat mudah }\end{array}$ & 45,45 & 54,55 & - & - & - & 100 \\
\hline $\begin{array}{l}\text { Pengemasan hand sanitizer alami } \\
\text { sangat mudah }\end{array}$ & 90,91 & 9,09 & - & - & - & 100 \\
\hline $\begin{array}{l}\text { Hand sanitizer alami sangat } \\
\text { bermanfaat dan dapat dijadikan } \\
\text { alternatif sebagai antiseptik pencuci } \\
\text { tangan. }\end{array}$ & 84,85 & 15,15 & - & - & - & 100 \\
\hline
\end{tabular}

Sumber: Diolah dari hasil PbM-SK, 2020

Terkait materi pelatihan disampaikan dengan jelas dan mudah dipahami, dari 33 orang responden peserta pelatihan, sebagian besar atau sebanyak 25 orang $(75,76 \%)$ menjawab sangat setuju dan sisanya 8 orang $(24,24 \%)$ menjawab setuju. Artinya penyampaian materi pada saat pelatihan sudah jelas dan dapat dipahami pleh peserta pelatihan.

Terkait Bahan dasar pembuatan hand sanitizer mudah didapatkan, dari 33 orang responden peserta pelatihan, sebagian besar atau sebanyak 30 orang $(90,91 \%)$ menjawab sangat setuju dan sisanya 3 orang $(9,09 \%)$ menjawab setuju. Artinya bahan dasar pembuatan hand sanitizer alami sangat mudah didapatkan oleh peserta pelatihan.

Terkait cara pembuatan hand sanitizer alami sangat mudah, dari 33 orang responden peserta pelatihan, sebanyak 15 orang atau $45,45 \%$ menjawab sangat setuju dan sisanya 18 orang $(54,55 \%)$ menjawab setuju. Artinya peserta pelatihan merasa cara pembuatan hand sanitizer alami tersebut mudah.

Terkait pengemasan hand sanitizer alami sangat mudah, dari 33 orang responden peserta pelatihan, Sebagian besar atau sebanyak 30 orang $(90,91 \%)$ menjawab sangat setuju dan sisanya sebanyak 3 orang $(9.09 \%)$ menjawab setuju. Artinya peserta pelatihan merasa mudah dalam pengemasan hand sanitizer alami.

Terkait kebermanfaatan hand sanitizer alami dan dapat dijadikan alternatif sebagai antiseptic pencuci tangan, dari 33 orang responden peserta pelatihan, sebagian besar atau sebanyak 28 orang $(84,85 \%)$ menjawab sangat setuju dan sisanya sebanyak 8 orang $(15,15 \%)$ menjawab setuju. Artinya peserta pelatihan merasa hand sanitizer alami ini sangat bermanfaat dan dapat dijadikan alternatif antiseptic pencuci tangan. 


\section{PENUTUP}

Berdasarkan pelaksanaan pelatihan pembuatan antiseptic (hand sanitizer) alami mampu menekan biaya untuk pengadaan pencegahan dalam menjaga hygine personal serta sanitasi lingkungan sekitar dengan baik dan benar. Dengan adanya pelatihan ini, dapat meningkatkan kesadaran masyarakat untuk menjaga kebersihan dan minat menggunakan hand sanitizer produk rumah-an sehingga ini dianggap jauh lebih praktis dibandingkan dengan mencuci tangan. Selain itu, masyarakat menjadi tercerahkan cara menerapkan kebiasaan baru ini dengan disiplin menjaga perilaku selalu hidup bersih dan sehat.

\section{UCAPAN TERIMA KASIH}

Tim penulis mengucapkan terimakasih kepada masyarakat Dusun Cikadongdong dan Pondok Pesantren Dadali Dinillah atas sambutan positif penyelenggaraan kegiatan pengabdian ini. Terimakasih kepada LP2M-PMP Universitas Siliwangi atas pendanaan kegiatan Pengabdian Kepada Masyarakat Skema Kesehatan (PbM-SK).

\section{DAFTAR PUSTAKA}

Kementerian Kesehatan Republik Indonesia. (2020). Kebijakan Penanggulangan Covid19 di Indonesia. Jakarta: Kementerian Kesehatan RI.

Murray. (2012). Biokimia Harper. Jakarta: EGC.

Suprapto, S. (2014). Simplisia dan Infusida Tanaman Obat. Jakarta: Rineka Cipta.

Wibawa, S. W. (2020). Nama Virus Corona Wuhan Sekarang SARS-COV-2. Kompas.com, 19 Februari 2020. Dapat diakses pada https://sains.kompas.com/read/2020/02/19/171500923/nama-virus-coronawuhan-sekarang-sars-cov-2-ini-bedanya-dengan-covid-19.

World Health Organization. (2020). Pencegahan dan Penanggulangan Penyakit Covid19. Jakarta : WHO \& Departemen Kesehatan RI. 